\title{
The effects of varying protein and energy intakes on the growth and body composition of pigs
}

\author{
2. The effects of varying both energy and protein intake \\ BY I. KYRIAZAKIS AND G. C. EMMANS \\ Genetics and Behavioural Sciences Department, The Scottish Agricultural College Edinburgh, \\ Kings Buildings, West Mains Road, Edinburgh EH9 $3 J G$
}

(Received 17 June 1991-Accepted 12 November 1991)

\begin{abstract}
The objective of the experiment was to define the form of the relationship between varying levels of protein and energy intake and the performance of young pigs. Forty-four young pigs were assigned at $12 \mathrm{~kg}$ live weight for 6 weeks either to an initial slaughter group $(n 8)$ or to one of the nine feeding treatments $(n)$ ); three allowances of a high-protein food with $355 \mathrm{~g}$ crude protein (nitrogen $\times 6 \cdot 25$; CP)/kg (P1, P2, P3) at three levels of feeding (L, M and H). Each feeding level was met by supplementing the allowance of feed $P$ with the appropriate amount of starch and each treatment had two males and two females. The rate of protein deposition was not affected by feeding level at the two lowest allowances of basal feed P (P1 and P2), but it increased with increasing the feeding level for the pigs on treatment P3. Males deposited more protein than females, but this effect was more pronounced with treatment P3. The rate of lipid deposition increased with each increase in the level of feeding and decreased with increasing the allowance of feed $P$. The calculated efficiency of protein utilization $\left(e_{p}\right)$ was expressed as a function of the energy:protein ratio in the feed (MJ metabolizable energy $/ \mathrm{kg}$ digestible $\mathrm{CP}$ ). The best model to describe the relationship was a linear-plateau model, with the maximum value for $e_{p}$ of 0.814 at $73 \mathrm{MJ} / \mathrm{kg}$. This relationship provided the basis of a model that could predict the response of a growing pig to its diet as rates of protein and lipid retention.
\end{abstract}

Body composition: Protein utilization: Energy intake: Protein intake: Protein retention: Pigs.

A previous experiment (Kyriazakis \& Emmans, 1992) examined the effects of energy intake at constant, high protein intake, on the rates of protein and lipid retention of growing pigs. It was found that protein retention depended on the rate of energy supply. The results, however, did not allow a distinction to be made between two models that predict the responses of a growing pig to its diet as rates of protein and lipid retention (Fuller \& Crofts, 1977; Campbell et al. 1985a, b).

The problems that are connected with the interpretation of these two models are associated with either their formulation or their quantitative predictions. The first model, proposed by Fuller \& Crofts (1977), suggests that the material efficiency with which protein is retained increases to a maximum as the energy: protein ratio of the feed is increased. This relationship between the efficiency of protein utilization $\left(e_{p}\right)$ and the energy:protein ratio in the feed was obtained from treatments either below or above the animals' protein requirements for maintenance. It is conceivable, however, that the $e_{p}$ for maintenance could be independent of the diet (Whittemore, 1983), and the relationship could have been significantly affected by this. The method of presentation of the results does not permit a separate analysis for the relationship between $e_{p}$ and the energy:protein ratio in the feed, below or above maintenance.

The model of Campbell et al. $(1985 a, b)$ suggests that the rate of protein retention has 
Table 1. The composition and chemical analysis of the basal feed $P(\mathrm{~g} / \mathrm{kg}$ fresh feed $)$

\begin{tabular}{lr}
\hline Ingredient $(\mathrm{g} / \mathrm{kg})$ & $343 \cdot 43$ \\
Wheat feed & $350 \cdot 00$ \\
Hipro soya bean & 186.96 \\
Fish meal & $41 \cdot 71$ \\
Maize oil & $11 \cdot 49$ \\
Limestone & $12 \cdot 32$ \\
Dicalcium phosphate & $0 \cdot 32$ \\
Salt & $7 \cdot 50$ \\
Vitamin and mineral supplement & $2 \cdot 50$ \\
Vitamin E supplement & $44 \cdot 05$ \\
Wood fibre & \\
Component (g/kg) & 888 \\
Dry matter & 355 \\
Crude protein (nitrogen $\times 6 \cdot 25)$ & 71 \\
Crude fibre & 71 \\
Diethyl ether extract & 87 \\
Ash & 17 \\
Calcium & 11 \\
Phosphorus & 86 \\
Starch & $12 \cdot 52$ \\
Metabolizable energy $(\mathrm{MJ} / \mathrm{kg})^{*}$ & \\
\hline
\end{tabular}

* Calculated by the European Association of Animal Production working group equation (Batterham, 1990).

a protein-dependent phase up to some level of protein supply, and then is energy-dependent only. This model is qualitative, and the point of changing from a protein to an energydependent phase is not clearly defined. In addition, the qualitative model was obtained from experiments where pigs were given different levels of feeds with different crude protein (nitrogen $\times 6.25$; CP) contents. Thus, the variables used were protein and feed intakes, instead of protein and energy intake. However, since the increase in feeding level does not only increase the rate of energy intake, but also increases the intake of other nutrients, it is possible that the response to energy intake above a certain protein supply could be a response to any non-protein nutrient as well as to energy.

The experiment described here was designed to define the form of the relationship between varying levels of protein and energy intake and the performance of young pigs. In addition, the use of two sexes (entire males and females) in the experimental design was expected to provide information on the effect of sex on the form of this relationship.

\section{MATERIALS AND METHODS}

Animals and housing. Forty-four Cotswold F1 Hybrid Large White $\times$ Landrace pigs (twenty-two entire males and twenty-two females) from eight litters were moved immediately after weaning into the individual cages of the experimental unit, which has been described previously (Kyriazakis \& Emmans, 1992). The weaned pigs had a mean live weight of 7.92 (SD 1.25) $\mathrm{kg}$ and were given free and continuous access to a high-quality commercial feed (Earlycare 404; BOCM Silcock).

Experimental feeds and design. A basal feed (P) with 12.52 MJ metabolizable energy (ME) $/ \mathrm{kg}$ and $355 \mathrm{~g} \mathrm{CP} / \mathrm{kg}$ was formulated (Table 1). The feed was of similar chemical and amino acid composition (Table 2) to the basal feed used in the previous experiment. It was also over-abundant, as defined by the Agricultural Research Council (1981), in minerals and vitamins, in order to maintain similar minerals: protein ratios to those of a standard commercial grower feed. 
Table 2. The determined amino acid composition of the basal feed $P(\mathrm{~g} / \mathrm{kg}$ crude protein $($ nitrogen $\times 6 \cdot 25))$

\begin{tabular}{lr}
\hline \hline & \\
Alanine & $49 \cdot 8$ \\
Arginine & $67 \cdot 2$ \\
Aspartic acid & $104 \cdot 2$ \\
Cystine & $16 \cdot 3$ \\
Glutamic acid & $181 \cdot 4$ \\
Glycine & $54 \cdot 3$ \\
Histidine & $23 \cdot 2$ \\
Isoleucine & $43 \cdot 1$ \\
Leucine & $74 \cdot 4$ \\
Lysine & $58 \cdot 7$ \\
Methionine & $21 \cdot 3$ \\
Methionine+cystine & $37 \cdot 6$ \\
Phenylalanine & $43 \cdot 7$ \\
Serine & $46 \cdot 3$ \\
Threonine & $38 \cdot 3$ \\
Tryptophan & $18 \cdot 8$ \\
Tyrosine & $40 \cdot 0$ \\
Valine & $46 \cdot 0$ \\
\hline
\end{tabular}

As each of the forty-four pigs used reached $12 \mathrm{~kg}$ live weight it was assigned either to an initial slaughter group $(n 8)$ or to one of the nine feeding treatments $(n 4)$. On each treatment half the pigs were entire males and half females. The feeding treatments were the combinations of three allowances of feed P (P1, P2 and P3) at three levels of feeding (low (L), medium (M) and high (H); Table 3). The feeding allowances were changed weekly; each feeding level was met by supplementing the allowance of feed $\mathrm{P}$ with the appropriate amount of starch (Cerestar GL 0340; Cerestar UK Ltd) and mixing it very thoroughly in a food mixer. The lowest level of feeding was chosen in order to ensure that pigs would not be cold, and the highest level of feeding was that expected to give no refusals; in the previous experiment there were some refusals at the start on the highest allowance used of $700 \mathrm{~g} / \mathrm{d}$ in week one.

The experiment lasted for 6 weeks from $12 \mathrm{~kg}$ live weight and at the end of the experiment all pigs were slaughtered and their bodies chemically analysed.

Management and slaughter procedures. The management and slaughter procedures were similar to those described in the previous experiment. On the 42 nd day of the experiment pigs were fed normally, and on the following morning were weighed and killed by an injection of pentobarbitol sodium. Their empty bodies were analysed for dry matter (DM) and the $\mathrm{N}$, ash and gross energy contents of the DM.

Statistical analysis. The results were analysed by an analysis of variance, as a randomized design with allowance of feed $\mathbf{P}$, level of feeding and sex as factors. Whenever there were some refusals of the offered feed, these were measured and used in the analysis of the results. As for the previous experiment, body lipid values were derived from the equation:

$$
\text { lipid }(\mathrm{g} / \mathrm{g} \mathrm{DM})=(\mathrm{GE}(\mathrm{kJ} / \mathrm{g} \mathrm{DM})-(23 \cdot 8 \times 6 \cdot 25 \times \mathrm{N}(\mathrm{g} / \mathrm{g} \mathrm{DM}))) / 39 \cdot 6 \text {. }
$$

\section{RESULTS}

The composition of the initial slaughter group at $13.04 \mathrm{~kg}$ live weight was $12.05 \mathrm{~kg}$ emptybody-weight, $1.812 \mathrm{~kg}$ protein and $1.121 \mathrm{~kg}$ lipid; there was no effect of sex. The compositions of the bodies of the pigs killed after 6 weeks are in Table 4. Increasing the 
Table 3. The allowances of feed $P$ and starch on the nine feeding treatments: three allowances of feed $P(P I, P 2$ and $P 3)$ at three levels of feeding $(L, M$ and $H)$ on the 1 st and 6 th week of the experiment; allowances were increased weekly on linear scales

\begin{tabular}{|c|c|c|c|c|c|}
\hline \multirow{3}{*}{$\begin{array}{c}\text { Allowance } \\
\text { of } P\end{array}$} & \multirow{3}{*}{$\begin{array}{c}\text { Feeding } \\
\text { level }\end{array}$} & \multicolumn{4}{|c|}{ Feed intake $(g / d)$} \\
\hline & & \multicolumn{2}{|c|}{ Week 1} & \multicolumn{2}{|c|}{ Week 6} \\
\hline & & Feed $\mathbf{P}$ & Starch & Feed $\mathbf{P}$ & Starch \\
\hline P1 & $\begin{array}{l}\mathrm{L} \\
\mathrm{M} \\
\mathrm{H}\end{array}$ & $\begin{array}{l}220 \\
220 \\
220\end{array}$ & $\begin{array}{l}220 \\
330 \\
440\end{array}$ & $\begin{array}{l}520 \\
520 \\
520\end{array}$ & $\begin{array}{r}520 \\
780 \\
1040\end{array}$ \\
\hline $\mathbf{P} 2$ & $\begin{array}{l}\mathrm{L} \\
\mathrm{M} \\
\mathrm{H}\end{array}$ & $\begin{array}{l}330 \\
330 \\
330\end{array}$ & $\begin{array}{l}110 \\
220 \\
330\end{array}$ & $\begin{array}{l}780 \\
780 \\
780\end{array}$ & $\begin{array}{l}260 \\
520 \\
780\end{array}$ \\
\hline P3 & $\begin{array}{l}\mathrm{L} \\
\mathrm{M} \\
\mathrm{H}\end{array}$ & $\begin{array}{l}440 \\
440 \\
440\end{array}$ & $\begin{array}{r}0 \\
110 \\
220\end{array}$ & $\begin{array}{l}1040 \\
1040 \\
1040\end{array}$ & $\begin{array}{r}0 \\
260 \\
520\end{array}$ \\
\hline
\end{tabular}

Table 4. The live weight, empty body-, protein and lipid weights of male $(M)$ and fermale $(F)$ pigs at 6 weeks given different allowances of a high-protein feed $(P)$ at different levels of feeding $(L, M$ and $H) \dagger$

\begin{tabular}{|c|c|c|c|c|c|c|c|c|c|}
\hline \multirow[b]{2}{*}{ Level of $P$} & \multirow{2}{*}{$\begin{array}{l}\text { Feeding } \\
\text { level }\end{array}$} & \multicolumn{2}{|c|}{$\begin{array}{l}\text { Live weight } \\
\quad(\mathrm{kg})\end{array}$} & \multicolumn{2}{|c|}{$\begin{array}{l}\text { Empty body-wt } \\
(\mathrm{kg})\end{array}$} & \multicolumn{2}{|c|}{$\begin{array}{l}\text { Protein wt } \\
\quad(\mathrm{kg})\end{array}$} & \multicolumn{2}{|c|}{$\begin{array}{l}\text { Lipid wt } \\
\quad(\mathrm{kg})\end{array}$} \\
\hline & & $\mathbf{M}$ & $\mathrm{F}$ & $\mathrm{M}$ & $\mathrm{F}$ & M & $\mathrm{F}$ & $\mathbf{M}$ & $\mathrm{F}$ \\
\hline $\mathbf{P 1}$ & $\begin{array}{l}\mathrm{L} \\
\mathrm{M} \\
\mathrm{H}\end{array}$ & $\begin{array}{l}28 \cdot 77 \\
31 \cdot 12 \\
32 \cdot 99\end{array}$ & $\begin{array}{l}29 \cdot 82 \\
30.57 \\
30.31\end{array}$ & $\begin{array}{l}27 \cdot 24 \\
29 \cdot 39 \\
30 \cdot 52\end{array}$ & $\begin{array}{l}27.94 \\
28.76 \\
28.41\end{array}$ & $\begin{array}{l}4.588 \\
4.613 \\
4.689\end{array}$ & $\begin{array}{l}4.752 \\
4.696 \\
4.411\end{array}$ & $\begin{array}{l}2 \cdot 565 \\
4 \cdot 439 \\
5 \cdot 306\end{array}$ & $\begin{array}{l}3.051 \\
3.864 \\
5.227\end{array}$ \\
\hline $\mathbf{P} 2$ & $\begin{array}{l}\mathrm{L} \\
\mathrm{M} \\
\mathrm{H}\end{array}$ & $\begin{array}{l}33.54 \\
36 \cdot 13 \\
39.91\end{array}$ & $\begin{array}{l}30 \cdot 90 \\
35 \cdot 14 \\
36 \cdot 00\end{array}$ & $\begin{array}{l}32 \cdot 92 \\
33 \cdot 17 \\
36 \cdot 65\end{array}$ & $\begin{array}{l}28.93 \\
32.92 \\
33.68\end{array}$ & $\begin{array}{l}5 \cdot 624 \\
5 \cdot 845 \\
6 \cdot 274\end{array}$ & $\begin{array}{l}4.964 \\
5.773 \\
5.589\end{array}$ & $\begin{array}{l}1 \cdot 509 \\
2 \cdot 387 \\
4 \cdot 011\end{array}$ & $\begin{array}{l}2.737 \\
3.243 \\
5 \cdot 135\end{array}$ \\
\hline P3 & $\begin{array}{l}\mathrm{L} \\
\mathrm{M} \\
\mathrm{H}\end{array}$ & $\begin{array}{l}31 \cdot 09 \\
36.03 \\
42 \cdot 97\end{array}$ & $\begin{array}{l}28 \cdot 79 \\
34 \cdot 10 \\
39 \cdot 87\end{array}$ & $\begin{array}{l}28 \cdot 33 \\
34 \cdot 02 \\
40 \cdot 34\end{array}$ & $\begin{array}{l}26.57 \\
31 \cdot 82 \\
36.95\end{array}$ & $\begin{array}{l}4.791 \\
6 \cdot 134 \\
7 \cdot 060\end{array}$ & $\begin{array}{l}4 \cdot 608 \\
5 \cdot 525 \\
6 \cdot 449\end{array}$ & $\begin{array}{l}1 \cdot 398 \\
2 \cdot 147 \\
3 \cdot 054\end{array}$ & $\begin{array}{l}2.045 \\
3.399 \\
4.036\end{array}$ \\
\hline SED & & \multicolumn{2}{|c|}{1.731} & \multicolumn{2}{|c|}{1.654} & \multicolumn{2}{|c|}{0.297} & \multicolumn{2}{|c|}{0.347} \\
\hline $\begin{array}{l}\text { Statistical significanc } \\
\text { Protein level }(\mathrm{P}) \\
\text { Feeding level }(\mathrm{F}) \\
\text { Sex }(\mathrm{S}) \\
\mathrm{P} \times \mathrm{F} \\
\mathrm{P} \times \mathrm{S} \\
\mathrm{F} \times \mathrm{S} \\
\mathrm{P} \times \mathrm{F} \times \mathrm{S}\end{array}$ & & & $\begin{array}{l}* \\
* \\
* \\
* \\
\text { * } \\
S \\
S \\
S \\
S\end{array}$ & $\begin{array}{l}* \\
* \\
* \\
*\end{array}$ & & $\begin{array}{l}* \\
* \\
* \\
* \\
\\
1 \\
1\end{array}$ & $\begin{array}{l}* \\
* \\
* \\
* \\
* \\
\text { S } \\
S \\
S \\
S\end{array}$ & & $\begin{array}{l}* \\
* \\
* \\
\text { * } \\
\text { * } \\
\text { * } \\
S \\
S\end{array}$ \\
\hline
\end{tabular}

SED, Standard error of difference; NS, not significant.

** $P<0.01$, *** $P<0.001$.

$\dagger$ For details of feed and treatments, see Tables $1-3$. 
Table 5. The daily rates of protein, lipid and gross energy $(G E)$ gains of male $(M)$ and female $(F)$ pigs when given different allowances of a high-protein feed $(P)$ at different levels of feeding $(L, M$ and $H)$ for 6 weeks from $12 \mathrm{~kg}$ live weight $\dagger$

\begin{tabular}{|c|c|c|c|c|c|c|c|c|c|c|}
\hline \multirow[b]{2}{*}{ Level of P } & \multirow{2}{*}{$\begin{array}{c}\text { Feeding } \\
\text { level }\end{array}$} & \multicolumn{3}{|c|}{ Protein gain $(\mathrm{g} / \mathrm{d})$} & \multicolumn{3}{|c|}{ Lipid gain $(\mathrm{g} / \mathrm{d})$} & \multicolumn{3}{|c|}{ GE gain $(g / d)$} \\
\hline & & $\mathbf{M}$ & $\mathrm{F}$ & Mean & M & $\mathrm{F}$ & Mean & $\mathbf{M}$ & F & Mean \\
\hline P1 & $\begin{array}{l}\mathrm{L} \\
\mathrm{M} \\
\mathrm{H}\end{array}$ & $\begin{array}{l}67 \\
69 \\
70\end{array}$ & $\begin{array}{l}70 \\
69 \\
62\end{array}$ & $\begin{array}{l}68 \\
69 \\
66\end{array}$ & $\begin{array}{r}34 \\
79 \\
100\end{array}$ & $\begin{array}{l}45 \\
65 \\
98\end{array}$ & $\begin{array}{l}40 \\
72 \\
99\end{array}$ & $\begin{array}{l}2 \cdot 94 \\
4 \cdot 77 \\
5 \cdot 61\end{array}$ & $\begin{array}{l}3 \cdot 45 \\
4 \cdot 24 \\
5 \cdot 36\end{array}$ & $\begin{array}{l}3 \cdot 20 \\
4 \cdot 51 \\
5 \cdot 49\end{array}$ \\
\hline $\mathbf{P} 2$ & $\begin{array}{l}\mathrm{L} \\
\mathrm{M} \\
\mathrm{H}\end{array}$ & $\begin{array}{r}92 \\
99 \\
105\end{array}$ & $\begin{array}{l}75 \\
95 \\
89\end{array}$ & $\begin{array}{l}83 \\
97 \\
97\end{array}$ & $\begin{array}{r}9 \\
31 \\
67\end{array}$ & $\begin{array}{l}38 \\
50 \\
94\end{array}$ & $\begin{array}{l}23 \\
41 \\
81\end{array}$ & $\begin{array}{l}2 \cdot 52 \\
3 \cdot 58 \\
5 \cdot 15\end{array}$ & $\begin{array}{l}3.28 \\
4 \cdot 24 \\
5 \cdot 84\end{array}$ & $\begin{array}{l}2.90 \\
3.91 \\
5 \cdot 50\end{array}$ \\
\hline P3 & $\begin{array}{l}\mathrm{L} \\
\mathrm{M} \\
\mathrm{H}\end{array}$ & $\begin{array}{r}73 \\
104 \\
126\end{array}$ & $\begin{array}{c}66 \\
86 \\
107\end{array}$ & $\begin{array}{r}69 \\
95 \\
117\end{array}$ & $\begin{array}{r}7 \\
24 \\
45\end{array}$ & $\begin{array}{l}21 \\
53 \\
67\end{array}$ & $\begin{array}{l}14 \\
38 \\
56\end{array}$ & $\begin{array}{l}2.00 \\
3.43 \\
4 \cdot 79\end{array}$ & $\begin{array}{l}2 \cdot 40 \\
4 \cdot 13 \\
5 \cdot 20\end{array}$ & $\begin{array}{l}2 \cdot 20 \\
3 \cdot 78 \\
5 \cdot 00\end{array}$ \\
\hline SED & & & 6.99 & & & $8 \cdot 13$ & & & 0.221 & \\
\hline $\begin{array}{l}\text { Statistical significance } \\
\text { Protein level }(\mathrm{P}) \\
\text { Feeding level }(\mathrm{F}) \\
\text { Sex }(\mathrm{S}) \\
\mathbf{P} \times \mathbf{F} \\
\mathrm{P} \times \mathrm{S} \\
\mathrm{F} \times \mathrm{S} \\
\mathrm{P} \times \mathrm{F} \times \mathrm{S}\end{array}$ & & & $\begin{array}{r}* * * \\
* * * \\
* * * \\
* * \\
\text { NS } \\
\text { NS } \\
\text { NS }\end{array}$ & & & $\begin{array}{c}* * * \\
* * * \\
* * * \\
\text { NS } \\
* * \\
N S \\
N S\end{array}$ & & & $\begin{array}{r}* * * \\
* * * \\
* * * \\
* \\
* * * \\
\text { NS } \\
\text { NS }\end{array}$ & \\
\hline
\end{tabular}

SED, Standard error of difference; NS, not significant.

* $P<0.05, * * P<0.01, * * * P<0.001$.

+ For details of feed and treatments, see Tables 1-3.

allowance of protein intake resulted in significant increases $(P<0.001)$ in the live weight, and empty body- and protein weights, and a significant decrease $(P<0.001)$ in the lipid weight of the pigs. However, the effect of increasing the feeding level on the live weight, and empty body- and protein weights was only evident on the highest allowance of feed $P$, where they were increased by increasing the level of feeding. Thus, the interactions between the allowance of feed $\mathrm{P}$ and feeding level on these measurements were highly significant (at most $P=0.01$ ).

The effect of sex on the body composition was also highly significant, with male pigs having heavier live weights and empty body- and protein weights, but lower lipid weights. None of the interactions with sex was significant.

The relationships between ash and protein and water and protein weights of the empty body of all pigs (including the initial slaughter group) were expressed by the equations:

$$
\begin{aligned}
& \text { ash weight }(\mathrm{kg})=0.191 \text { protein weight } \quad \text { (residual SD (RSD) 0.0603), } \\
& (\mathrm{SE} 0.0018) \\
& \text { water weight }(\mathrm{kg})=5.14 \text { protein weight } \mathrm{t}^{0.845} \pm 0.0369 \text { water weight, } \\
& (\mathrm{SE} 0.0128)
\end{aligned}
$$

with no allowance of feed $P$, level of feeding or sex effects on the two relationships.

The daily rates of protein, lipid and energy deposition are shown in Table 5. There was a significant interaction between the effects of the allowance of feed $\mathrm{P}$ and the feeding level on the rate of protein deposition. This was due to the effect of level of feeding on the rate 
of protein deposition of animals given the highest allowance of feed $\mathrm{P}$ (allowance P3). At the other two allowances of feed $P$ the increase in the level of feeding did not affect significantly the rate of protein deposition.

The effect of sex on the rate of protein deposition was highly significant $(P<0.001)$, with male pigs depositing more protein than females. This effect of sex was more pronounced at the highest allowance of feed P (allowance P3) than at the lowest one (treatment P1). However, the interaction between the allowance of feed $P$ and sex on the rate of protein deposition just failed to meet significance $(0 \cdot 1>P>0.05)$. None of the other interactions with sex was significant.

The rate at which lipid was deposited increased with each increase in the level of feeding and decreased with increasing the allowance of feed $P(P<0 \cdot 001)$. Pigs on the lowest allowance of feeding and at the highest allowance of feed $\mathbf{P}$ (treatment $\mathrm{P} 3 \mathrm{~L}$ ) deposited as little as $7 \mathrm{~g}$ lipid/d. The effect of sex on the rate of lipid deposition was also highly significant $(P<0.001)$, with females depositing significantly more lipid than male pigs. This effect was least evident on the lowest allowance of feed P (allowance P1) and, therefore, the interaction between level of protein intake and sex was highly significant $(P<0.01)$.

\section{DISCUSSION}

The results suggest that at low levels of protein intake the rate of protein deposition is dependent only on the rate of protein supply (allowances P1 and P2); at high rates of protein intake protein deposition depends only on the energy supply (allowance P3). The latter part of the results is consistent with those of the previous experiment (Kyriazakis \& Emmans, 1992) where it was found that the rate of protein deposition was increased as energy intake was increased at a constant, non-limiting protein allowance. The results of both experiments thus reject the model of Fuller \& Crofts (1977) which suggested that $e_{p}$ was a continuous function of the energy: protein ratio of the feed.

The net efficiency of ideal protein utilization above maintenance was calculated, as for the previous experiment (Kyriazakis \& Emmans, 1992), from the equation:

$$
\mathrm{PR}(\mathrm{kg} / \mathrm{d})=e_{p}\left(\left(\mathrm{FI} \times \mathrm{FCP} \times \mathrm{v} \times d_{c p}\right)-\mathrm{MP}\right),
$$

where PR is the protein retained $(\mathrm{kg} / \mathrm{d}), \mathrm{FI}$ is feed intake $(\mathrm{kg} / \mathrm{d}), \mathrm{FCP}$ is the food CP content $(\mathrm{kg} / \mathrm{kg}), \mathrm{v}$ is the value of digested protein in relation to ideal protein (calculated to be 0.83 for feed $\mathrm{P}$ ), $d_{c p}$ is the digestibility of CP (assumed to be 0.85 for the CP of feed P) and $\mathrm{MP}$ is the ideal protein requirement $(\mathrm{kg} / \mathrm{d})$ calculated from the equation:

$$
\operatorname{MP}(\mathrm{kg} / \mathrm{d})=0.0040 \times \mathrm{P}
$$

where $\mathrm{P}$ is the protein weight of the pigs. The $e_{p}$ values calculated from equation 4 for the nine feeding treatments and the two sexes are in Table 6.

At low levels of protein intake (level P1) the $e_{p}$ values were independent of feeding level, and consequently of energy intake, and had an average value of 0.83 . This value was close to the $e_{p}$ value of 0.81 estimated in the previous experiment when protein intake was limiting and the energy supply was adequate. However, at high allowances of protein intake (level P3) the $e_{p}$ values were significantly affected by the level of energy intake and decreased as the amount of energy in the diet was decreased.

The results of the two experiments are in Fig. 1, where the $e_{p}$ values calculated for both experiments were plotted against the energy:protein ratio in the feed (expressed as $\mathrm{MJ}$ $\mathrm{ME} / \mathrm{kg}$ digestible $\mathrm{CP}$ ). The best and simplest model to describe the relationship between the two variables was a linear-plateau model. The advantage of a linear-plateau model over a linear-exponential one, which could describe the relationship equally well, was that it 
Table 6. The efficiency of protein utilization $\left(\mathrm{e}_{\mathrm{p}}\right)$ of male $(M)$ and female $(F)$ pigs when given different allowances of a high-protein feed $(P)$ at different levels of feeding $(L, M$ and $H)$ for 6 weeks from $12 \mathrm{~kg}$ live weight $\dagger$

\begin{tabular}{|c|c|c|c|c|}
\hline \multirow[b]{2}{*}{ Level of $P$} & \multirow{2}{*}{$\begin{array}{l}\text { Feeding } \\
\text { level }\end{array}$} & \multicolumn{3}{|c|}{$e_{p}$} \\
\hline & & $\mathrm{M}$ & $\mathrm{F}$ & Mean \\
\hline P1 & $\begin{array}{l}\mathrm{L} \\
\mathrm{M} \\
\mathrm{H}\end{array}$ & $\begin{array}{l}0.815 \\
0.836 \\
0.865\end{array}$ & $\begin{array}{l}0.854 \\
0.848 \\
0.759\end{array}$ & $\begin{array}{l}0.834 \\
0.842 \\
0.812\end{array}$ \\
\hline $\mathrm{P} 2$ & $\begin{array}{l}\mathrm{L} \\
\mathrm{M} \\
\mathrm{H}\end{array}$ & $\begin{array}{l}0.720 \\
0.778 \\
0.837\end{array}$ & $\begin{array}{l}0.585 \\
0.746 \\
0.697\end{array}$ & $\begin{array}{l}0.652 \\
0.762 \\
0.767\end{array}$ \\
\hline P3 & $\begin{array}{l}\mathrm{L} \\
\mathrm{M} \\
\mathrm{H}\end{array}$ & $\begin{array}{l}0.415 \\
0.601 \\
0.741\end{array}$ & $\begin{array}{l}0.375 \\
0.496 \\
0.623\end{array}$ & $\begin{array}{l}0.395 \\
0.549 \\
0.682\end{array}$ \\
\hline SED & & & 0.058 & \\
\hline $\begin{array}{l}\text { Statistical significanc } \\
\text { Protein level }(\mathrm{P}) \\
\text { Feeding level }(\mathrm{F}) \\
\text { Sex }(\mathrm{S}) \\
\mathbf{P} \times \mathbf{F} \\
\mathbf{P} \times \mathrm{S} \\
\mathrm{F} \times \mathrm{S} \\
\mathrm{P} \times \mathbf{F} \times \mathrm{S}\end{array}$ & & & $\begin{array}{r}* * * \\
* * * \\
* * \\
* * \\
\text { NS } \\
\text { NS } \\
\text { NS }\end{array}$ & \\
\hline
\end{tabular}

SED, Standard error of difference; NS, not significant.

** $P<0.01$, *** $P<0.001$.

$\dagger$ For details of feed and treatments, see Tables $1-3$.

needed the estimation of only three as opposed to four variables needed for the linearexponential model. Thus, the ascending part of the model was described by the linear equation:

$$
\begin{aligned}
& e_{p}=0.0112 \times(\mathrm{FEC} / \mathrm{DCPC}) \quad(\mathrm{RSD} 0.0716), \\
& \quad(\mathrm{SE} 0.00022)
\end{aligned}
$$

where FEC is the feed energy content of the feed (MJ ME $/ \mathrm{kg}$ feed) and DCPC is the digestible $\mathrm{CP}$ content of the feed $(\mathrm{kg} / \mathrm{kg}$ feed). There were no significant experiment, treatment or sex effects on the relationship. There were also no treatment or sex effects on the plateau part of the model, and the mean value of $e_{p}$ was 0.814 (SE 0.018); the inflection point was, thus, estimated to be at 72.55 (SE 1.53) MJ $/ \mathrm{kg}$. Equation 6 and Fig. 1 suggest that $e_{p}$, when protein is limiting, is directly proportional to the energy: protein ratio in the feed and has a maximum value of 0.81 . Such a maximum estimated value justifies the assumption that in practical cases $e_{p}$ has a constant value of about 0.85 (Whittemore, 1983; Stranks et al. 1988), since normal pig feeds will have an ME:DCPC ratio above the $72.55 \mathrm{MJ} / \mathrm{kg}$. The minimum value of $e_{p}$ could also be estimated from equation 6 , when the feed contains protein as the only energy source (i.e. $1 \mathrm{~kg} \mathrm{DCPC} / \mathrm{kg}$ feed). In this case the $\mathrm{ME}$ : DCPC ratio will be around $18 \mathrm{MJ} / \mathrm{kg}$ and, therefore, the $e_{p}$ estimated from equation 6 is $e_{p}=0 \cdot 20$.

One of the major advantages of expressing the $e_{p}$ as a function of the energy:protein ratio is that by combining equations 4 and 6 we get:

$$
\mathrm{PR}(\mathrm{kg} / \mathrm{d})=0.0112 \times \mathrm{FI} \times \mathrm{FEC} \times \mathrm{v}-0.0112 \times \mathrm{FEC} \times \mathrm{MP} / \mathrm{DCPC} \text {, }
$$




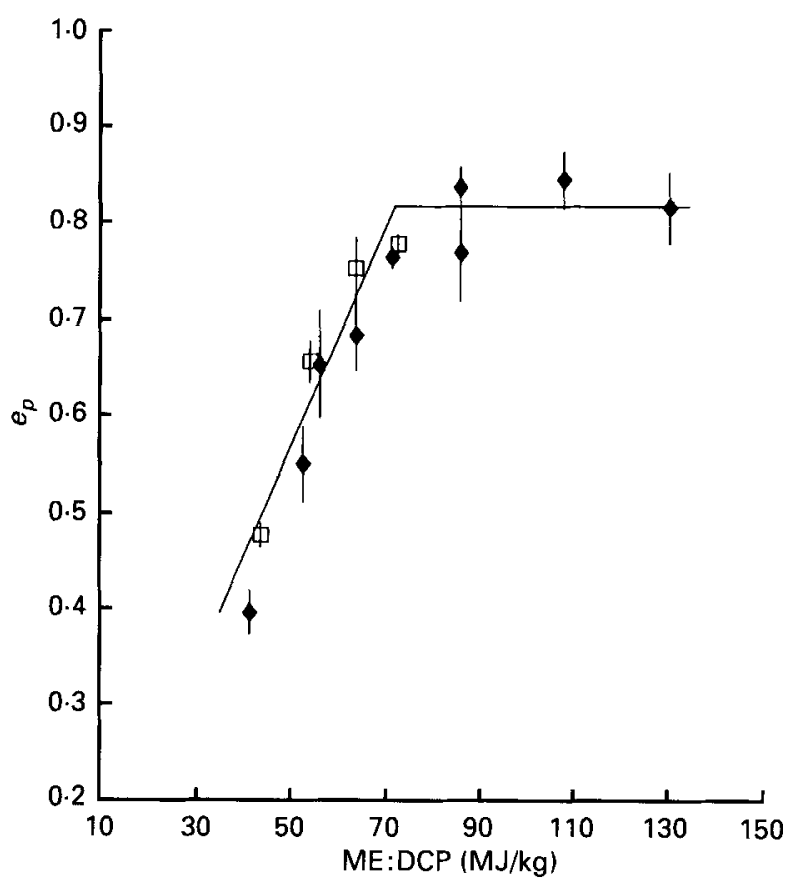

Fig. 1. The efficiency of protein utilization $\left(e_{p}\right)$ for the present experiment $(\bullet)$ and the experiment of Kyriazakis \& Emmans (1992) ( $\square$ ) as a function of the energy (FEC) : protein (DCPC) ratio in the feed (MJ metabolizable energy $(\mathrm{ME}) / \mathrm{kg}$ digestible crude protein (nitrogen $\times 6.25)$ ). The regression equation for the ascending part of the relationship was:

$e_{p}=0.0112(\mathrm{SE} 0.0002) \times(\mathrm{FEC} / \mathrm{DCPC})$, residual SD 0.072, inflection point at $72.55(\mathrm{SE} 1.53) \mathrm{MJ} / \mathrm{kg}$.

For details of feeds and treatments, see Tables $1-3$.

or

$$
\text { PR }(\mathrm{kg} / \mathrm{d})=0.0112 \times \mathrm{MEI} \times \mathrm{v}-0.0112 \times \mathrm{FEC} \times \mathrm{MP} / \mathrm{DCPC},
$$

where MEI is the daily rate of ME intake (MJ/d). Assuming that v, FEC and DCPC are constant for a given food (McDonald et al. 1988) and ideal protein requirements for maintenance (MP) are constant for an animal of a given protein weight (Whittemore, 1983), equation 8 suggests that, for a given food, protein retention is a linear function of the daily energy intake when the feed has an energy: protein ratio below $72.55 \mathrm{MJ} \mathrm{ME} / \mathrm{kg}$ DCPC. This suggestion is in agreement with that of Black \& Griffiths (1975) who have also proposed that for growing lambs of any particular live weight their $\mathrm{N}$ requirements are a linear function of ME intake. However, Black \& Griffiths (1975) have also suggested that protein retention is a function of the live weight of the lambs as well as the energy content of the feed, whereas equations 6 and 8 suggest that at low energy:protein ratios in the feed the rate of change of protein retention per unit energy intake is constant and independent of the live weight or the state of the animal.

Equations 6,7 and 8 can be put in the form of an algorithm to predict the rate of protein retention, $P R(\mathrm{~kg} / \mathrm{d})$, on controlled feeding for a pig with a potential rate of protein retention of $P R_{\max }(\mathrm{kg} / \mathrm{d})$; Appendix). This algorithm was used to predict $P R$ for a pig of about $30 \mathrm{~kg}$ live weight and a $P_{\max }$ of $0.150 \mathrm{~kg} / \mathrm{d}$ given different allowances $(0.8-1.8 \mathrm{~kg} / \mathrm{d}$ in $0.2 \mathrm{~kg} / \mathrm{d}$ steps) of feeds of different DCPC values $(0.075-0.300 \mathrm{~kg} / \mathrm{kg}$ in steps of $0.025 \mathrm{~kg} / \mathrm{kg}$ ). The feeds were all assumed to have $14 \mathrm{MJ}$ digestible energy (DE) $/ \mathrm{kg}$ and 


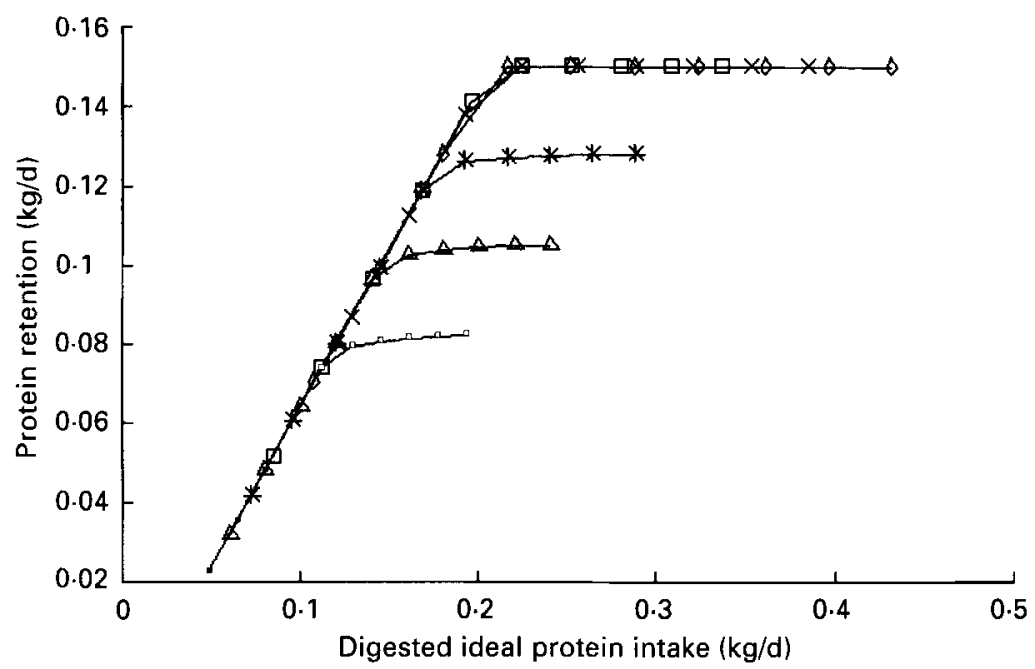

Fig. 2. The predicted rates of protein retention $(\mathrm{kg} / \mathrm{d})$ of a pig of $30 \mathrm{~kg}$ live weight, given access to feeds with different protein contents at six levels of feeding (for details of feeds and treatments, see pp. 622-623). (口), $0.8 \mathrm{~kg} / \mathrm{d} ;(\triangle), 1.0 \mathrm{~kg} / \mathrm{d} ;\left(^{*}\right), 1.2 \mathrm{~kg} / \mathrm{d} ;(\square), 1.4 \mathrm{~kg} / \mathrm{d} ;(\times), 1.6 \mathrm{~kg} / \mathrm{d} ;(\mathrm{O}), 1.8 \mathrm{~kg} / \mathrm{d}$.

their ME to be given by $\mathrm{ME}=\mathrm{DE}(0.997-0.000189 \mathrm{CP}(\mathrm{g} / \mathrm{kg})$ ) (Agricultural Research Council, 1981). Fig. 2 replicates the values produced by Campbell et al. $(1985 a, b)$ from experiments where growing pigs were given access to feeds with different concentrations of dietary $\mathrm{CP}$ at different levels of feed intake. The predictions are consistent with the suggestion that the rate of protein deposition depends only on protein supply, up to some level of supply; above this level it depends only on the energy supply (Black et al. 1986). The precise point of change from the protein- to the energy-dependent phase could be identified from equation 6 .

The linear-plateau relationship between $e_{p}$ and the energy:protein content in the feed, as presented in Fig. 1, suggests that neither the ascending linear relationship nor the plateau were significantly influenced by sex. This implies that the protein and energy effects on protein deposition are similar for the two sexes and, thus, male and female animals will deposit protein at the same rate during the protein-dependent phase of protein deposition. It is, however, envisaged that the sexes will have different genetic potentials for protein deposition and, thus, the maximum rate of protein deposition during the energy-dependent phase will be affected by sex. The suggestion that the protein and energy effects on protein deposition are similar for the two sexes is directly opposite to the findings of Campbell \& Taverner (1988) who found that the rate of protein deposition was higher in entire males than castrated pigs at low levels of protein intake. The other interesting question which arises from the model of Fig. 1 is whether strain or genotype differences are expected to have an effect on this relationship. The results of Leclercq \& Saadoun (1982) with broiler chickens and Ellis et al. (1983) with pigs suggest that the linear part of the relationship will be affected, but the plateau part will not. In a comparison of control and selected lines of Large White pigs, Ellis et al. (1983) found that, although selection was based on growth performance under ad lib. feeding, pigs from the selected line exhibited faster protein deposition than those from the control line when feed was offered in restricted amounts (low protein intakes).

The effects of varying the levels of protein and energy intake on the rates of lipid deposition of the growing pig can be then seen as the indirect result of the concomitant 
effect of protein and energy intake on the rates of protein deposition and, thus, the amount of energy available for lipid synthesis. The interaction between the allowance of feed $\mathrm{P}$ and the feeding level suggests that on treatment $\mathrm{P} 3 \mathrm{H}$ female pigs had reached their potential for protein deposition and, thus, had more energy available for lipid synthesis than male pigs. The results do not provide any further evidence that there was any other effect of sex on the rates of lipid deposition, and oppose the view that there is an effect of sex on lipid synthesis at low levels of feed intake (Leclercq \& Saadoun, 1982).

The actual ME intake $\left(\mathrm{ME}_{\mathrm{INT}}\right)$ was $6 \%$ higher than that predicted by the Agricultural Research Council (1981) equation which relates $\mathrm{ME}_{I N T}$ to protein (PR) and lipid retention (LR) and scaled live weight $\left(\mathrm{LW}^{0 \cdot 63}\right)$.

When the results of the present experiment were combined with those by Kyriazakis \& Emmans (1992) the relationship between $\mathrm{ME}_{\mathrm{INT}}$ and the other variables was:

$$
\begin{gathered}
\mathrm{ME}_{\mathrm{LNT}}(\mathrm{MJ} / \mathrm{d})=40.9 \mathrm{PR}+62.2 \mathrm{LR}+0.793 \mathrm{LW}^{0.63} \quad(\mathrm{RSD}=0.620) . \\
(\text { SE 5.11) (SE 2.83) } \quad \text { (SE 0.071) }
\end{gathered}
$$

The use of both sets of data in the estimation of the relationship resulted in better estimation of the coefficients by reducing the errors associated with them and resolving the correlations between the so called independent variables. The only significant correlation was that between PR and $\mathrm{LW}^{0.63}$ of 0.75 .

The results provide the basis of a model that could predict the response of a growing pig to its diet as rates of protein and lipid retention. They also provide information on the much sought relationships (Rao \& McCracken, 1990; Laswai et al. 1991) between protein and energy on the nutrient utilization of modern pig genotypes. The knowledge of the relationships between energy and protein intake on the partition of nutrients between protein and lipid could be useful for the design of biologically and economically efficient feeds and feeding strategies for modern pig genotypes.

This work was supported by BOCM Silcock Ltd. The authors would like to acknowledge the technical assistance of A. MacAndrew and P. Finnie and to thank Dr A. J. Taylor of BOCM Silcock Ltd for his enthusiastic support throughout the project.

\section{REFERENCES}

Agricultural Research Council (1981). The Nutrient Requirements of Pigs. Slough: Commonwealth Agricultural Bureaux.

Batterham, E. S. (1990). Prediction of the dietary energy value of diets and raw materials for pigs. In Feedstuff Evaluation, pp. 267-281 [J. Wiseman and D. J. A. Cole, editors]. London: Butterworths.

Black, J. L., Campbell, R. G., Williams, I. H., James, K. J. \& Davies, G. T. (1986). Simulation of energy and amino acid utilisation in the pig. Research and Development in Agriculture 3, 121-145.

Black, J. L. \& Griffiths, D. A. (1975). Effects of live weight and energy intake on nitrogen balance and total N requirement of lambs. British Journal of Nutrition 33, 399-413.

Campbell, R. G. \& Taverner, M. R. (1988). Genotype and sex effects on the relationship between energy intake and protein deposition in growing pigs. Journal of Animal Science 66, 676-686.

Campbell, R. G., Taverner, M. R. \& Curic, D. M. (1985a). The influence of feeding level on the protein requirement of pigs between 20 and $45 \mathrm{~kg}$ liveweight. Animal Production 40, 489-496.

Campbell, R. G., Taverner, M. R. \& Curic, D. M. (1985b). Effects of sex and energy intake between 48 and $90 \mathrm{~kg}$ liveweight on protein deposition in growing pigs. Animal Production 40, 497-503.

Ellis, M., Smith, W. C., Henderson, R., Whittemore, C. T., Laird, R. \& Phillips, P. (1983). Comparative performance and body composition of control and selection line Large White pigs. 3. Three low feeding scales for a fixed time. Animal Production 37, 253-258.

Emmans, G. C. \& Fisher, C. (1986). Problems in nutritional theory. In Nutrient Requirements of Poultry and Nutrition Research, Poultry Symposium no. 19, pp.9-39 [C. Fisher and K. N. Boorman, editors]. London: Butterworths.

Fuller, M. R. \& Crofts, R. M. J. (1977). The protein sparing effect of carbohydrate. 1. Nitrogen retention of growing pigs in relation to diet. British Journal of Nutrition 38, 479-488. 
Kyriazakis, I. \& Emmans, G. C. (1992). The effects of varying protein and energy intakes on the growth and body comparisons of pigs: 1 . The effects of energy intake at constant, high protein intake. British Journal of Nutrition 68, 603-613.

Laswai, G. H., Close, W. H., Sharpe, G. E. \& Keal, H. D. (1991). The influence of level of feeding on nutrient partition and energy metabolism in pigs of different growth potential. Animal Production 52, 570.

Leclercq, B. \& Saadoun, A. (1982). Comparison of energy metabolism in genetically lean and fat lines of broilers. In Energy Metabolism of Farm Animals. European Association of Animal Production Publication no. 29 , pp. 274-277. Switzerland: Vitznan.

McDonald, P., Edwards, R. A. \& Greenhalgh, J. F. D. (1988). Animal Nutrition, 4th ed. London: Longman.

Rao, D. S. \& McCracken, K. J. (1990). Effect of protein intake on energy and nitrogen balance and chemical composition of gain in growing boars of high genetic potential. Animal Production 51, 389-397.

Stranks, M. H., Cooke, B. C., Fairbairn, C. B., Fowler, N. G., Kirby, P. S., McCracken, K. J., Morgan, C. A., Palmer, F. G. \& Peers, D. G. (1988). Nutrient allowances for growing pigs. Research and Development in Agriculture 5, 71-88.

Whittemore, C. T. (1983). Development of recommended energy and protein allowances for growing pigs. Agricultural Systems 11, 159-186.

If

then

but if

then

Otherwise, if

then

and

but if

then
APPENDIX

$(\mathrm{ME} / \mathrm{DCPC})>72.55$

$\mathrm{PR}=0.814 \times((\mathrm{FI} \times \mathrm{DCPC} \times \mathrm{v})-\mathrm{MP})$,

$$
\mathrm{PR}>\mathrm{PR}_{\max }
$$

$\mathrm{PR}=\mathrm{PR}_{\max }$.

$$
\begin{gathered}
(\mathrm{ME} / \mathrm{DCPC})<72.55 \\
e_{p}=0.0112 \times(\mathrm{ME} / \mathrm{DCPC}) \\
\mathrm{PR}=e_{p} \times((\mathrm{FI} \times \mathrm{DCPC} \times \mathrm{v})-\mathrm{MP}), \\
\mathrm{PR}>\mathrm{PR}_{\max } \\
\mathrm{PR}=\mathrm{PR}_{\max } .
\end{gathered}
$$

where ME is metabolizable energy content of the feed $(\mathrm{MJ} / \mathrm{kg}), \mathrm{DCPC}$ is the digestible CP content of the feed $(\mathrm{kg} / \mathrm{kg}), P R$ is the protein retained $(\mathrm{kg} / \mathrm{d}), F I$ is feed intake $(\mathrm{kg} / \mathrm{d}), \mathrm{v}$ is the value of digested protein in relation to ideal protein, MP is the ideal protein requirement $(\mathrm{kd} / \mathrm{d}), P_{\max }$ is the maximum protein retention $(\mathrm{kg} / \mathrm{d})$ and $e_{p}$ is the net efficiency of ideal protein utilization. 